\title{
YOUNGSTER'S ATTITUDES TO SCHOOL-BASED PREVENTION PROGRAMS FOCUSED ON DRUG ABUSE PREVENTION
}

\author{
Barbora Odraskova ${ }^{1}$, Michal Kozubik ${ }^{2}$, Lukas Odraska ${ }^{3}$
}

\begin{abstract}
This paper focuses on primary prevention of drug addiction, in particular the primary prevention programs implemented in school environments. It contains the results of a quantitative research conducted using a non-standardized questionnaire method. The study objective was to identify differences in attitudes of a group of pupils towards the issue of drug addiction before and after they completed the school-based prevention program. The study found that after completing the school-based prevention program there was improvement in attitudes towards the issue of drug addiction in the specific group of pupils. The number of appropriate answers to the question "Alcohol makes people happy" increased by $18.82 \%$. respondents $(62.70 \%)$ disagreed that they would adapt themselves if their opinion differed to the majority. The number of positive answers to the question "Smoking is addictive" increased by $13.66 \%$; the number of positive answers to the question "Drinking alcohol is harmful" increased by $24.93 \%$; and all respondents agreed with the statement that smoking threatens health.
\end{abstract}

UDC Classification: 314/316, DOI: http://dx.doi.org/10.12955/cbup.v4.774

Keywords: prevention programs, drug addiction, primary prevention.

\section{Introduction}

Today, primary drug abuse prevention is particularly important because children are maturing early and drug abuse issues are no longer taboo for this age group. This is a consequence of a modern age where children have access to mobile phones and Internet for all the information they desire. Drug addiction is a social issue. Already cases exist of pupils n primary school experimenting with drugs. The current cause of this phenomenon can include insufficient awareness of harmful effects, psychological problems a desire to belong, family problems, and many others. Therefore, greater attention on implementing prevention programs and various prevention actions to prevent adverse socio-pathological effects is needed. We consider focusing on primary prevention aimed at informing children about the dangers of drugs as most important. Subsequently, the main objective of this survey is to identify possible differences in the attitudes of a group of pupils towards the issue of drug addiction before and after they complete a school-based prevention program. In the paper we focus on two areas: general awareness and peer influence. Similar issues and studies have been discussed by Ishaak, De Vries, and Van der Wolf (2014), D'Amico, E.J., Tucker, J.S., Miles, J.N.V., Zhou, A.J., Shih, R.A., Green, H.D. (2012), Midford, (2010), and Martino-McAllister (2004).

According to Abadinský (2002), prevention means various actions and strategies that aim to prevent or minimize the problems of a variety of issues, in this case drug abuse and addiction.

Ondrejkovič et al. (2009) understood prevention at schools and school facilities to be prevention that provides optimal conditions for healthy development of children, and involves pedagogical and psychological measures that are focused on eliminating potential causes of disorders in psychosocial development, and early elimination of new problems in children and youth.

For primary prevention to be efficient, it needs to be part of school syllabi and based on team cooperation between schools, families, and various institutions (Wilson \& Kolander, 2011).

From a literature review, we chose several prevention programs for the purpose of this paper. The first program chosen was "School without Alcohol, Drugs, and Cigarettes" ("Škola bez alkoholu, drog a cigariet"), developed by I. Novotný with an aim of teaching participants how to change patterns of risky behaviors to protective ones, as well as how to create an antidrug atmosphere (Bakošová, 2008). The second "Healthy Lifestyle" ("Zdravý životný štýl") is an educational program focusing on prevention of drug abuse and AIDS, healthy diet, and sex education by improving knowledge, and

\footnotetext{
${ }^{1}$ Barbora Odraskova, Constantine the Philosopher University in Nitra, Faculty of Social Sciences and Health Care; barbora.odraskova@ukf.sk

${ }_{2}^{2}$ Michal Kozubík, Constantine the Philosopher University in Nitra, Faculty of Social Sciences and Health Care; mkozubik@ukf.sk

${ }^{3}$ Lukas Odraska, Comenius University in Bratislava, Faculty of Physical Education and Sport; lukas.odraska@gmail.com
} 
strengthening desired attitudes and social skills in the discussed areas (Hroncová, 2006). Others included the drug abuse prevention programs organized by the Ministry of Interior of the Slovak Republic, particularly by the Presidium of the Police Force of the Slovak Republic. The most interesting activities among these programs for children are possibly "Malicious Drug" ("Zákerná droga"), "Bingo!...for my money!" ("Bingo!...za moje peniaze!"), and "Cheers! Thanks, I'd rather not!” (Na zdravie! Ďakujem, radšej nie!"), which have common aims of informing audiences about addictions, and the harmfulness, of such. These highlight the problems caused by drug addicts including their effects on the people around them, particularly their families, and aim to make children think more about being responsible for their own lives (Rác, 2011). Another "Peer Programme", is based on information on the positive influence of opinions and attitudes among peers without direct intervention from people outside the peer group. This involves a method of cooperation between young people in sharing their knowledge and information to promote antidrug attitudes (Janíková, 2007).

\section{Data and Methodology}

The survey was conducted by convenience sampling with inclusion criteria: 1) a pupil in Year 4 or 5 of primary school, and 2) participating in the specific prevention program: "Choose Correctly" ("Vyber si správne"), which had been organized by the primary prevention club, Domino in Nitra, specifically by Dr. Alena Mrázová. The sample included 51 respondents. We conducted a quantitative study; according to Hendl (2005), which was based on a structured data collection with the use of tests, questionnaires, and observation. We used a questionnaire approach, which is a survey tool, most often used in quantitative research (Ondrejkovič, 2007). The questionnaire consisted of several questions on various aspects such as experiences with alcohol and cigarette consumption, influence of media and peers, and the ability to refuse drugs. The questionnaires were distributed to respondents before participating in the primary prevention program and then approximately one month after they completed the program, to assess program's effectiveness. The scope of the study was general awareness of the pupils understanding about commercially available drugs and peer influence in their decision making.

\section{Survey Results}

The number of appropriate answers to the question "Alcohol makes people happy" increased by $18.82 \%$ after completing the program (Figure 1).

Figure 1: Alcohol makes people happy

\begin{tabular}{|c|c|c|c|}
\hline \multicolumn{4}{|l|}{$80.00 \%$} \\
\hline \multicolumn{4}{|l|}{$70.00 \%$} \\
\hline \multicolumn{4}{|l|}{$60.00 \%$} \\
\hline \multicolumn{4}{|l|}{$50.00 \%$} \\
\hline \multicolumn{4}{|l|}{$40.00 \%$} \\
\hline \multicolumn{4}{|l|}{$30.00 \%$} \\
\hline \multicolumn{4}{|l|}{$20.00 \%$} \\
\hline \multicolumn{4}{|l|}{$10.00 \%$} \\
\hline $0.00 \%$ & I agree & I do not agree & I do not know \\
\hline before & $29.50 \%$ & $62.70 \%$ & $7.80 \%$ \\
\hline after & $19.60 \%$ & $74.50 \%$ & $5.90 \%$ \\
\hline : Author & & & \\
\hline
\end{tabular}


The number of respondents agreeing with the statement "Alcohol is a drug" increased by $22.24 \%$ after completing the program (Figure 2).

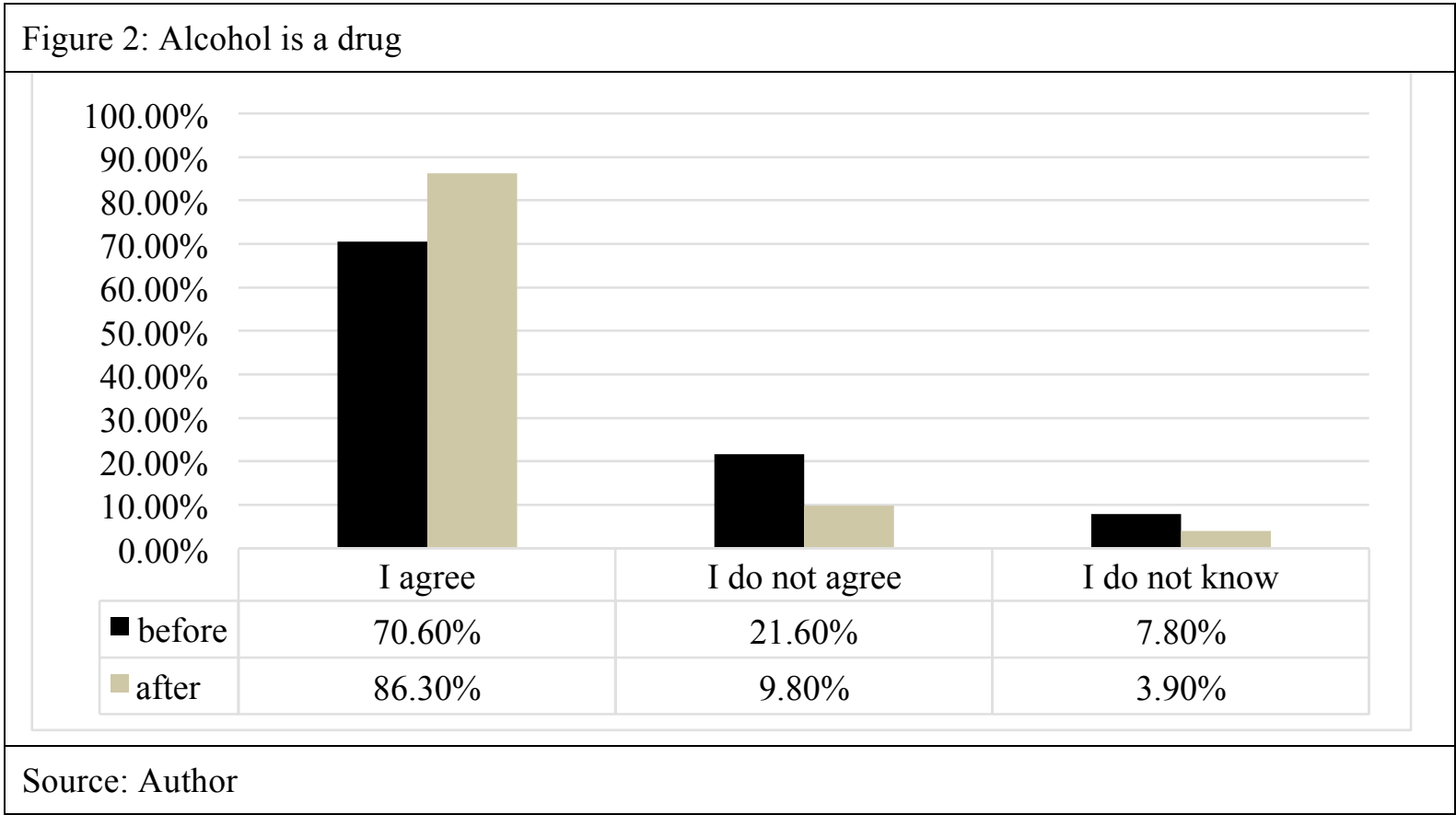

The number of positive answers to the question "Drinking alcohol is harmful" increased by $24.93 \%$ after completing the program (Figure 3 ).

Figure 3: Drinking alcohol is harmful

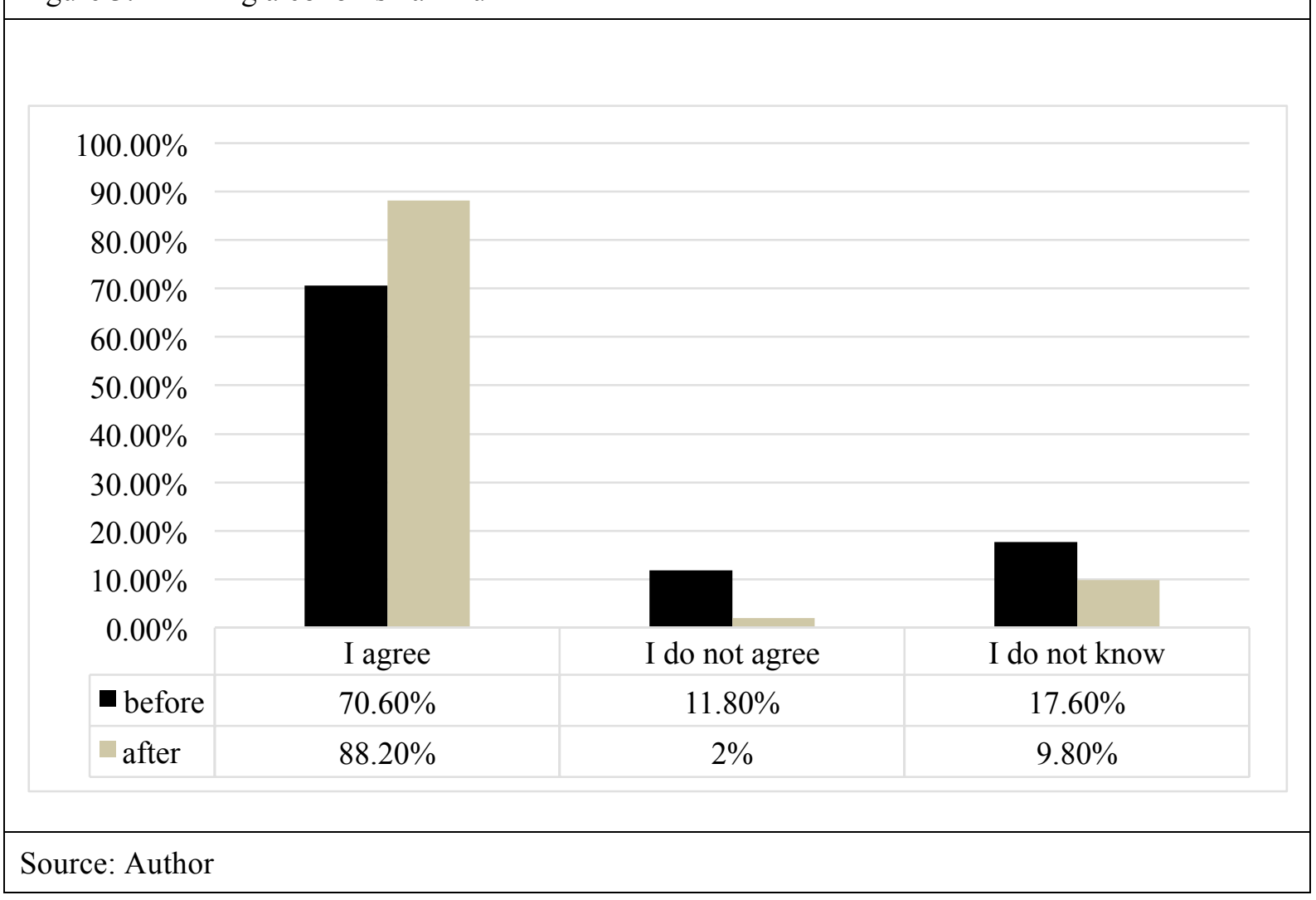

After completing the program, almost all respondents agreed with the statement that smoking threatens health (Figure 4). 
Figure 4: Smoking threatens health

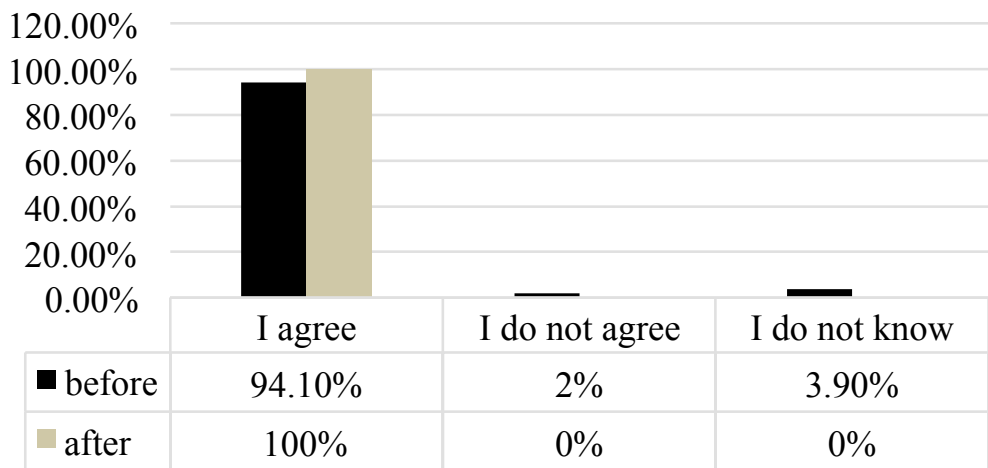

Source: Author

The number of positive answers to the question "Smoking is addictive" increased by $13.66 \%$ after completing the program (Figure 5).

Figure 5: Smoking is addictive

\begin{tabular}{|c|c|c|c|}
\hline $100.00 \%$ & \multicolumn{3}{c|}{} \\
\hline $50.00 \%$ & & & \\
\hline
\end{tabular}

Source: Author

The respondents were more confident in their opinions after completing the program (Figure 6).

Figure 6: Often I have a problem to express my opinion

\begin{tabular}{|c|c|c|c|}
\hline \multirow{2}{*}{\multicolumn{4}{|c|}{$100.00 \%$}} \\
\hline & & & \\
\hline $0.00 \%$ & I agree & I do not agree & I do not know \\
\hline - before & $41.20 \%$ & $47 \%$ & $11.80 \%$ \\
\hline after & $27.40 \%$ & $62.70 \%$ & $9.80 \%$ \\
\hline
\end{tabular}

Source: Author

After completing the program, $94.10 \%$ of the respondents did not agree with the statement "what my friends think is always correct and true" (Figure 7). 
Figure 7: What my friends think is always correct and true

\begin{tabular}{|c|c|c|c|}
\hline \multirow[t]{2}{*}{$\begin{array}{r}100.00 \% \\
80.00 \% \\
60.00 \% \\
40.00 \% \\
20.00 \% \\
0.00 \%\end{array}$} & & 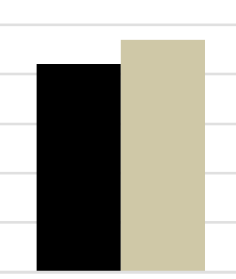 & \\
\hline & I agree & I do not agree & I do not know \\
\hline before & $9.80 \%$ & $84.30 \%$ & $5.90 \%$ \\
\hline after & $3.90 \%$ & $94.10 \%$ & $2 \%$ \\
\hline
\end{tabular}

Source: Author

After completing the program, $62.70 \%$ of the respondents disagreed with adapting themselves to the majority if their opinion is different (Figure 8).

Figure 8: If my opinion differs from the majority's, I adapt myself

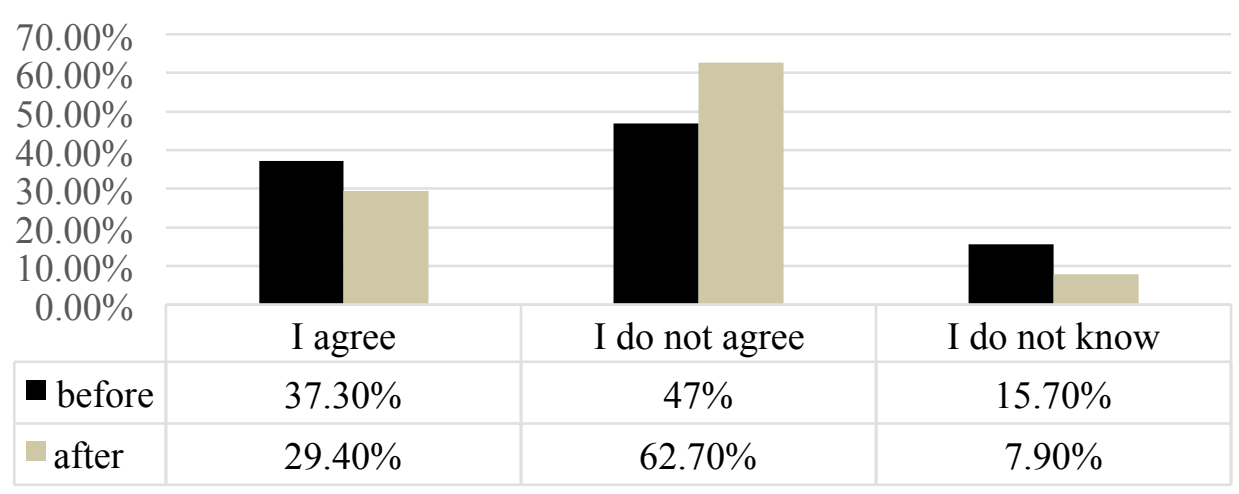

Source: Author

The number of positive answers to the question "I always decide by myself" increased by $13.15 \%$ after completing the program (Figure 9).

Figure 9: I always decide by myself

$100.00 \%$

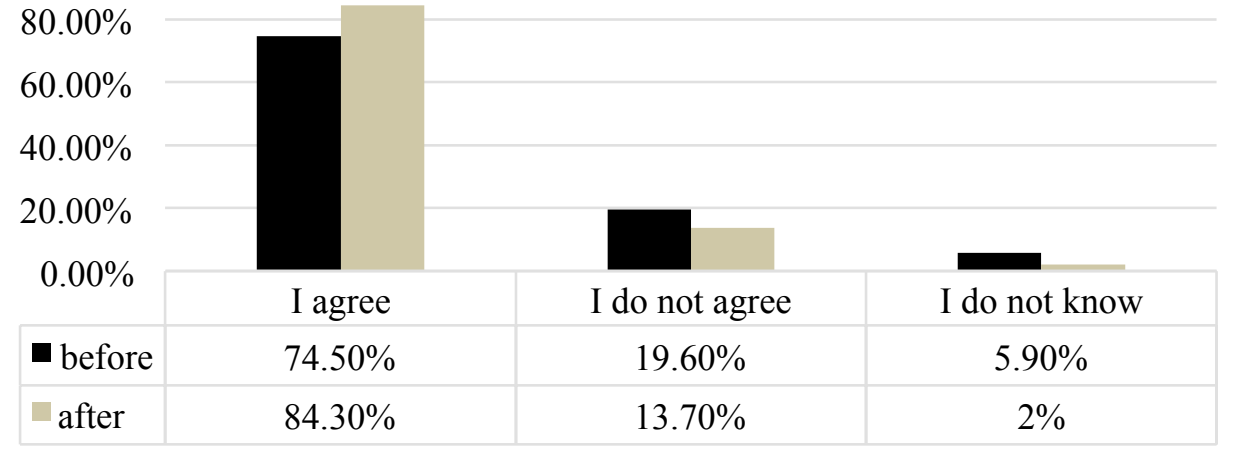

Source: Author 


\section{Discussion}

The results show that the respondents' answers changed after completing the specific prevention program. We report that after completing the primary prevention program "Choose Correctly", the respondents had a better general overview of issues than before. The objective of focusing on peer influence was supported by several questions in the questionnaire. After completing the school-based prevention program, we found improvement in this scope. The number of appropriate answers to the question "Alcohol makes people happy" increased by $18.82 \%$ after completing the program. In addition, after completing the program, $62.70 \%$ of the respondents disagreed that they would adapt themselves if their opinion was different to the majority; the number of positive answers to the question "Smoking is addictive" increased by $13.66 \%$; and all respondents agreed with the statement that smoking threatens health. The number of positive answers to the question "Drinking alcohol is harmful" increased by $24.93 \%$ after completing the program. The pupils were active in participating in the survey, as evidenced by the amount of data collected. The applied form of prevention appears effective, as confirmed by the results of our survey.

We note that drug addiction is a pressing social problem today. Alcohol and cigarette abuse by young people seriously impairs and threatens their development. The cause of this phenomenon can be various, from problematic family relationships to efforts in belonging among peers to insufficient awareness of adverse drug effects on children and youth. Therefore, drug abuse prevention plays an increasingly important role in the education process. The aim of education on drug abuse prevention is not only to inform on harmful and addictive effects of drugs and other substances but also to create and develop the appropriate attitudes of children and youth towards drugs. Effective prevention is better than solving consequences of drug addiction.

The survey indicated the significance of drug abuse prevention in its primary form. Firstly, prevention needs to focus on changing attitudes of pupils towards drugs and this can be influenced by teachers.

Teachers' attitudes can be the basis of prevention because teachers are in everyday contact with pupils, and therefore can identify changes in student behaviors and respond to negative events early. The issue of drug and substance abuse by young people is the subject matter of international and Slovak research studies and discussions; but, in spite of the measures and preventive actions, the incidence of addictions in young people remains alarming. Educating children on the existence and consequences of drug abuse is an important preventive element. The actions directed at drug abuse and addiction prevention and on youth protection are priorities not only for Slovakia but worldwide. It is necessary to seek ways that enable young people to obtain positive attitudes towards life values, and to affect them by accurate and reliable information in the family, schools, and leisure spheres of life.

\section{Conclusion}

The priority of our survey was to identify possible differences in attitudes of a specific group of pupils towards the issue of drug addictions before and after they completed a school-based prevention program. There was recordable improvement after completing the school-based prevention program in both objectives. However, these results are valid for the study sample only, and cannot be used as a generalization.

\section{References}

Abadinský, H. (2002). Drug use and abuse: comprehensive introduction. p. 272. ISBN 978-049-5809-913.

Bakošová, Z. (2008). Social pedagogy as life support. p. 222. ISBN 978-80-969944-0-3.

D'Amico, E. J., Tucker, J. S., Miles, J. N. V., Zhou, A. J., Shih, R. A., \& Green, H. D. (2012). Preventing Alcohol Use with a Voluntary After-School Program for Middle School Students: Results from a Cluster Randomized Controlled Trial of Choice. Prevention science. p. 415-425.

Hendl, J. (2005). Qualitative research. Basic Methods and Applications. p. 408. ISBN 80-7367-040-2.

Hroncová, J., Kraus, B., Emmerová, I., Hudecová, A., Jusko P., Kouteková, M., Mal’ová, M., Šebian, M., Vacek, P., \& Vavrinčíková, L. (2006). Social Pathology for social workers and teachers. p. 252. ISBN 80-8083-223-4.

Ishaak, F., De Vries, N. K., \& Van der Wolf, K. (2014), Test implementation of a school-oriented drug prevention program "Study without Drugs": pre- and post-testing for effectiveness. BMC Public health. 10.1186/1471-2458-14-590.

Janíková, K. (2007). A new form of leisure and extracurricular activities - peer volunteering. In: Youth and Society. ISSN 1335-1109, roč. 13 , č. 2 , p. 21-33.

Martino-McAllister, J. M. (2004). Pulsar: A qualitative study of a substance abuse prevention program. Journal of drug education. p. 89-103. 
Midford, R. (2010). Drug prevention program for young people: where have we been and where should we be going? Addiction. p. 1688-1695.

Ondrejkovič, P. (2007). Introduction to the methodology of social-scientific research. p. 248. ISBN 978-80-224-0970-4.

Ondrejkovič, P.,Bakošová, Z., Bednárik, R., Kasanová, A., Lubelcová, G., Marková, D., Masár, O., Miková. Z., Nábelek, L., Poláková, Z., Poliaková, E., Rusnáková, J., Sedláková, D., \& Šramová, B. (2009). Social pathology. 580 s. ISBN 978-80224-1074-8.

Rác, I. (2011). Social pathology and prevention of socio-pathological phenomena. p. 141. ISBN 978-80-8094-913-6.

Wilson, R., \& Kolander, C. H. (2011). Drug abuse prevention. p. 332. ISBN 978- 0- 7637-7158-4. 